persons. Their rights were established and guaranteed by treaties signed jointly by their forefathers and the Canadian Government. Although it is possible that their treaty rights might be abrogated and the Indians made subject to restrictive legislation with respect to caribou hunting, such an approach would undoubtedly raise strong moral and legislative conflicts. In addition, without the co-operation of the Indians the enforcement of such restrictions might be extremely difficult and meet with little success. People eking out a tenuous subsistence in a harsh climate cannot be expected to react favourably to any measures that make their existence more difficult.

The problem of reducing the hunting of caribou by Treaty Indians is a complex sociological one that is not likely to be resolved by direct legislative and enforcement measures. An intensified educational and persuasive programme might obtain their co-operation in preventing unnecessary waste of caribou, but it would necessarily be long-term. The real problem of increasing their standard of living must be resolved before we can expect any lasting results from a conservation education programme. The problem is urgent and complex; the solution will be difficult and costly. But if the valuable and irreplaceable human and caribou resources are to be saved it must be resolved. The matter is too urgent for the long-term approach alone. The outcome is still in doubt.

\title{
A New Post in the Galapagos
}

\section{A CONSERVATION Officer $A_{\text {for the Galapagos Islands }}$} has been attached to the Charles Darwin Foundation's Research Station, thanks to a grant from the New York Zoological Society. $\mathrm{He}$ is Sr. Miguel Castro. As a native of the Galapagos, well known and respected there, it is hoped that he will be able to persuade the islanders of the importance of conservation. Among his first tasks is the eradication,

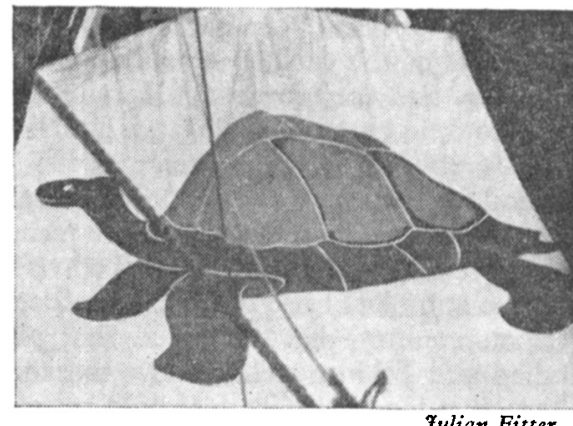

Julian Fitter

Galapagos Emblem on Beagle's Foresail. on some of the uninhabited islands, of the introduced goats which are the chief enemies of the wildlife, thanks to their thorough grazing. The new Director of the Station, Roger Perry, formerly a member of the BBC's Natural History Unit, takes over from Dr. David Snow in September. Dr. Jean Dorst, formerly Hon. Secretary of the Foundation, has succeeded Dr. Van Straelen as Chairman. The Foundation's new ship, Beagle, given by the World Wildlife Fund and the Gulbenkian Trust, a photograph of which appeared in our April issue, arrived in the islands on May 7th, and is now in full use. The picture of the Galapagos tortoise on the foresail of Beagle was taken during the first voyage by a member of the crew from the crosstrees on the foremast. The name Galapagos means tortoise. 